\title{
REPAIRS v. REPLACEMENT — NEW DIRECTIONS OUT OF THE QUAGMIRE?
}

\author{
BY FRANK D. JONES, Q.C.*
}

\begin{abstract}
The article reviews the problematic area in tax law as to whether to characterize an outlay as a "repair", which results in a full tax deduction for the year of the outlay, or as a "replacement", which allows the amortizement of the outlay over a number of years. Professor Jones then discusses a new way to deal with this problem.
\end{abstract}

\section{TABLE OF CONTENTS}

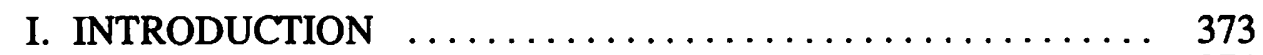

II. JURISPRUDENCE $\ldots \ldots \ldots \ldots \ldots \ldots \ldots \ldots \ldots \ldots \ldots \ldots, 374$

III. CONCLUSION $\ldots \ldots \ldots \ldots \ldots \ldots \ldots \ldots \ldots \ldots \ldots \ldots \ldots, 387$

\section{INTRODUCTION}

A perennial question facing the business taxpayer is, "May I fully deduct business expenditures in the year of the outlay, or must I capitalize these outlays and amortize them over a number of years?" A sub-species of this general question is whether or not an outlay should be characterized as a "repair" or "replacement". The answer, of course, affects whether the expense is characterized as a full deduction in the year of expenditure or a capitalization of such expenditure.

An examination of this problem reveals a history of controversy and judicial scrutiny. Little guidance has been given to taxpayers by way of underlying principles.

The Canadian Tax Service puts the problem this way:

Any expenditure which enlarges, improves or enhances the original value or utility of an asset is generally regarded as a non-deductible capital expenditure, subject to annual deductions for capital cost allowance . . . whereas any expenditure which maintains or restores to its original condition a business asset or property from which income is derived is a deductible, revenue or expenditure.

In the abstract, the distinction seems plausible. The difficulty comes in applying this distinction to a particular fact situation. One quickly realizes the vague generalities are not of much assistance.

Buckley L.J. (as he then was) in Lurcutt v. Wakely and Wheeler' states:

". 'Repair' and 'renew' are not words expressive for a clear contrast", and "repair is restoration by renewal or replacement of subsidiary parts of a whole. Renewal, as distinguished from repair, is reconstruction of the entirety, meaning by the entirety not necessarily the whole but substantially the whole subject matter under discussion"'. When does one cross the line and reconstruct "substantially the whole subject matter' "? What are classified as "subsidiary parts" of a whole? These questions are fundamental to an understanding of tax consequences of a particular act but, unfortunately, the courts have given little guidance and, indeed, have perhaps muddied the waters even further in their decisions".

To reduce this problem, the author suggests that a new test be employed for distinguishing between repair and replacements. Under this proposed test, the Court would look to whether or not the repairs increased the "networth" of the business.

* Professor of Law, University of Alberta.

1. [1911] 1 K.B. 905 at 923-4. 
The Court could approach the problem as one of simple financial quantification rather than straining for a linguistic distinction on the basis of function. If there is a marked increase in the value of the business asset, the repair is treated as a capital expenditure.

\section{JURISPRUDENCE}

In the writer's opinion, it is unfortunate that the Privy Council case of Rhodesia Railways Limited v. Collector of Income Tax, Bechuanaland Protectorate ${ }^{2}$ has not been more extensively analyzed by Canadian courts. It is suggested that this case may have provided answers to questions which have proved perplexing to Canadian courts and may have prevented some of the current problems. ${ }^{3}$

The Rhodesia Railways case concemed a deduction taken by Rhodesia Railways Limited in relation to work which was part of a general scheme of renewal. Steel sleepers were installed in place of wooden sleepers for half of the railway track. The question was whether this expenditure was a replacement or a repair. The tax section under consideration was s.15.1 of the Bechuanaland Protectorate Tax Proclamation 1922.4

The railway line was originally laid down in 1896-97 and was thereafter maintained in the ordinary course of business. This normal maintenance involved the occasional replacement of a split rail or bad sleeper. By November 1929, the track was generally found to be in a worn and dangerous state and required heavy repairs. A program of renewal was adopted. The renewed line was of the same weight as the old line, with new steel sleepers for $38^{1 / 2}$ miles and new wooden sleepers for two miles. In addition to replacing the wooden sleepers with steel sleepers, additional steel sleepers were introduced in carrying out the work, but the cost of these additional sleepers was charged to capital. The result of the renewals, apart from the additional sleepers, was to bring the track back to normal condition, and the line as renewed was not capable of giving more service than the original line.

2. [1933] A.C. 360 .

3. M.N.R. v. Vancouver Tugboat Company Ld. [1957] C.T.C. 178.

4. "15.1 For the purpose of ascertaining the taxable income of any person there shall be deducted from the income of such person - (a) losses and outgoings actually incurred in the territory by the taxpayer in the production of his income, and including also such expenses incurred outside the territory in the production of the taxable income as the Collector may allow; provided such losses or outgoings are not of a capital nature; (b) sums expended for the repairs of property occupied for the purpose of trade or in respect of which income is receivable, and sums expended for the repair of machinery, implements, utensils, and articles employed by the taxpayer for the purposes of his trade; such sums shall be the actual expenditure incurred by the taxpayer during the year of assessment; (c) such sum as the Collector may think just and reasonable as representing the diminished value by reason of wear and tear during the year of assessment of any machinery, implements, utensils and articles used by the taxpayer for the purposes of his trade; provided that where a deduction has been allowed under paragraph (b) of this sub-section the Collector shall take into consideration the sum allowed under that paragraph; - provided that in no case shall any allowance be made for the depreciation of buildings or other structures or works of a permanent nature; . . . . ( $f$ ) an allowance in respect of any machinery, implements, utensils and articles used by the taxpayer for the purposes of his trade which have been scrapped by such taxpayer during the year of assessment, such allowance to be the difference between the original cost to such taxpayer of such machinery, implements, utensils or articles and the total amount arrived at by adding all the allowances made in respect thereof under paragraph (c) of this sub-section to any amount or the value of any advantages accruing to the taxpayer in respect of the sale or other disposal of such machinery, implements, utensils and articles." 
Thus, this case highlights several elements which have proved vexing for Canadian courts. These are:

1. an extraordinary program over and above the normal maintenance program;

2. new technology used in the replacement of wooden sleepers with steel sleepers;

3. a segregation for something done over and above that which was originally there (i.e. the additional sleepers);

4. a functional consideration (i.e. the renewed railway line was not capable of giving more service than the original line); and,

5. the statutory scheme discussed insofar as depreciation is concerned. All of these issues have been considered by Canadian courts from time to time and the lack of a cohesive approach has contributed to the confusion with which we are faced.

The Privy Council decided that the expenditures made should be classified as repairs and hence fully deductible in the year of expenditure. At page 376-377, the Court states:

In the present instance, the renewals effected constituted no improvement, they merely made good the line so as to restore it to its original state. As such, in their Lordship's opinion, they were 'repairs' within the meaning of section 15-s.1(b) of the Proclamation and the cost of them did not constitute an outgoing of capital nature within the meaning of section 15-s.1(a). It follows that the sum of 252,174 expended on this work by the Appellants is deductible from their income for the purposes of ascertaining their taxable income.

Their Lordships quoted Buckley L.J. in Lurcott v. Wakely and Wheelers in his attempt to define the words "repair" and "renew", and went on to say:

Periodical renewal by section of the rails and sleepers of a railway line as they wear out by use is in no sense a reconstruction of the whole railway and is an ordinary incident of railway administration. The fact that the wear although continuous is not and cannot be made good annually does not render the work of renewal when it comes to be effected necessarily a capital charge. The expenditure here in question was incurred in consequence of the rails having been wom out in eaming the income of the previous years in which the tax had been paid without dectuction in respect of such wear, and represented the cost of restoring them to a state in which they could continue to earn income. It did not result in the creation of any new asset; it was incurred to maintain the Appellants' existing line in a state to eam revenue. The analogy of a wasting asset which appears to have effected the minds of the Special Court has really no application to such a case as the present. 6

The idea that assets have an innate wasting effect has been used by Canadian courts to disallow an expense as a repair expense. ' The argument is that to allow such a claim is, in effect, to allow a deduction in respect of depreciation of the asset.

Their Lordships further stated:

Nor do their Lordships agree that expenditure in order to form a permissible deduction must have been incurred in the production of the actual years' income which is the subject of the assessment, if by this it is meant that the benefit of the expenditure must not extend beyond the year of assessment, for very many repairs have the result of enabling income to be earned in future years as well as in the year in which they are affected.8

Therefore, the court rejects the idea that one must strictly compartmentalize the taxation years when dealing with the repair/replacement issue. In this writer's

5. Supra n.1.

6. [1933] A.C. 374.

7. Supra n.3.

8. [1933] A.C. 374-5. 
opinion, this reflects a realistic view of the situation. Unfortunately, the Tax Court of Canada has on occasion used the compartmentalization approach when dealing with repair/replacement issues. It is suggested this approach has added to the complexities and confusion in Canadian law. ${ }^{9}$

The presence or absence in a statute of depreciation provisions was argued in Rhodesia Railways case and has been a major influencing factor in Canada in such cases as M.N.R. v. Vancouver Tugboat Company Limited.$^{10}$ This case is a monument to the ingenuity and flexibility of the legal mind. On the one hand it has been argued that the absence of depreciation provisions in a statute is a reason to disallow repair/renewal expenditures. It has also been argued that the presence of depreciation provisions in a taxing statute is a reason to disallow repair/renewal expenditures."

A fundamental aspect of this problem was identified by their Lordships in Hiland Ry. Co. v. Special Commissioner of Income Tax ${ }^{12}$ at pp. 375 and 376. In the Hiland case, steel rails were substituted for previous iron rails and the question to be decided by the court was a very narrow one, viz.: was the cost of the additional improved rails a capital cost or an income cost? In the Hiland Ry. Co case, the Court held that the cost should be charged to capital. This result was viewed with approval by the Privy Council in Rhodesia Railways even though the result in that case was an allowance of the expenditure against income. What then is the difference? It would seem that the difference is where there is an increase in the networth to the individual, that increase is a capital increase, whereas if the status quo is maintained and there is no networth increase, the expenditures to maintain the status quo are chargeable against income. The Lord President (Inglis) in the Hiland Railways Company case, as quoted by MacMillan in the Rhodesia Railways case, seems to support this idea when he states:

It is not taking away rails that are worn out or partially worn out and renewing them in a whole or in part along the whole line. That would not alter the character of the line; it would not affect the nature of the heritable property possessed by the company. But what has been done is to substitute one kind of rail for another - steel rails for iron rails. Now that is a material alteration and a very great improvement in the corpus of the heritable estate belonging to the company and so stated surely is a charge against capital.

In accepting this position, the Privy Council in Rhodesia Railways looked at whether or not there was such an increase in the "networth" (heritable) estate from a functional point of view. It is suggested that if this principle were adopted by Canadian courts it would resolve many of the complexities that now exist. The potential adoption of this idea has been given impetus by Mr. Justice Jackett in the Canada Steamship Lines case ${ }^{13}$ when he emphasizes that the problem should be looked at from a businessman's point of view. If one were to adopt the functional networth approach as expressed in the Hiland and Rhodesia Railways cases, it is suggested that a rational basis would exist for the deductibility/nondeductibility of repairs/replacement expenses in the business-commercial setting.

9. Coleman v. M.N.R. [1984] C.T.C. 2725 at 2727; Wager v. M.N.R. [1985] C.T.C. 2208 at 2211.

10. [1951] C.T.C. 178.

11. Rhodesia Railways Limited v. Collector of Income Tax Bechuanaland Protectorate [1933] A.C. 368 at 375 .

12. 16 R 950; 2 Tax Cases 485.

13. Canada Steamship Lines Limited v. M.N.R. [1966] C.T.C. 255. 
It is suggested by this writer that the court in the Rhodesia Railways case viewed the railway from a functional or operative point of view. It examined whether the expenses outlaid resulted in any increase in the networth of the business itself and answered in the negative. In the Hiland Railway case, the Court answered the same question in the affirmative. Of course, it must be remembered that in the Rhodesia Railways case, the amount expended on the additional sleepers was capitalized by the company and was not at issue. If they had not been so treated, and the company had attempted to deduct their costs against income, the Railway's costs would have been attributed to capital as a result of the functional test.

M.N.R. v. Vancouver Tugboat Company Limited ${ }^{14}$ is one of the cases which has given rise to many of the problems existing in Canadian jurisprudence. The company operated a tugboat service on the west coast of Canada. It had nine tugs, seven of which it owned and two of which it chartered. One of the tugs owned by the company was a wooden motor vessel purchased in 1947 from War Assets Corporation for $\$ 20,000$. When purchased, the vessel was equipped with a single $600 \mathrm{hp}$ Vivian Diesel Engine. The company refitted the tug at an additional cost of $\$ 24,000$. In 1950 and 1951, the company experienced repair problems with the engine. In 1952, the company was faced with the necessity of either carrying out a complete overhaul and rebuilding of the engine at a cost of $\$ 20,000$, or the purchase of a suitable new engine at $\$ 26,500$ plus freight and installation for a total of $\$ 42,086.71$. The latter arrangement was adopted and its cost written off as a repair. The new engine performed exactly the same function as the previous engine. It delivered no more power, could not make the tug go any faster and allowed the tug to haul the same number of barges. It was recognized by the Court that "with a fleet of tugs in operation, the matter of replacing engines is obviously one that must be faced frequently, although at irregular intervals." 15

This case illustrates one of the major problems in Canadian tax jurisprudence. In the Tax Appeal Board decision, Mr. Fischer characterized the capital asset as the tugboat, and the engine as a repair to the tugboat, thus allowing the deduction. It was conceded in argument and seemingly accepted by the Court that "the cost of repairs to capital equipment is ordinarily a deductible item provided they have become necessary through the income earning operations of the taxpayer." The Exchequer Court, however, disallowed the deduction. The Court stated that because the taxpayers chose to install a new engine rather than repair the old engine, and because the cost of such installation was higher, it was therefore a capital expenditure. The Court observed:

I think it may be safely said that the expenditure was to cover the accumulation of past wear and tear and to prevent the necessity for so many repairs and so much loss of time in the future. While the expense of replacing engines is a recurring one in the sense that it recurs in respect of each tug once in five, eight, or ten years, I do not think the expenditure can be classed as one made to meet a continuous demand. . . . no doubt there will be wear and tear each year beyond what is restored in repairs in the year and the advantage will ultimately be exhausted, but, in my opinion, that does not affect the nature of such advantage as capital. If any deduction from income is to be allowed in respect of such exhaustion, in my view, it must be by way of an allowance of a kind permitted under the exception to section 12(1)(b). . . . But I am somewhat influenced by the size of the expenditure in question in relation to what were described as abnormally high repairs to the tug in the years 1949,1950 and $1951 . \ldots .16$

14. [1957] C.T.C. 178.

15. Supra n.3, at 181.

16. Id., at $\mathbf{1 8 6}$. 
With respect, there are some troubling concepts enunciated in this judgment. First, the question of the size of the expenditure has been expressly negated by Jackett J. (as he then was) in Canada Steamship Lines v. M.N.R.:

"I cannot accept the view that the cost of repairs ceases to be current expenses and becomes outlay of capital merely because the repairs required are very extensive or because the cost is substantial." 17

The same argument was made in Rhodesia Railways by Sir Thompson Inskip who was acting for the Crown. He pointed out that the total original cost of the railway was about 3 million and the renewals when completed would cost about 1.25 million and would absorb the whole profit of the line for the next five years. The Lordships placed no weight on this argument.

The Court in Vancouver Tugboat Company distinguished Rhodesia Railways on the basis that the provisions of the Income Tax Proclamation in that country were quite different from that of the Income Tax Act in Canada.$^{18}$ With respect it is suggested that the net effect of the Bechuanaland Protectorate Income Tax Act was the same as we have in Canada. Under this legislation, it was necessary to ascertain whether or not expenditures should be classified as capital due to the fact that section 15(a) prohibited capital expenditures as deductions. The allowance of repairs as deductible items in section 15(b), it is suggested, adds little or nothing and has the same net effect in Canada. This last thought was also challenged by the Court in Vancouver Tug where it was stated:

I do not think, especially in view of the provision of the statute for capital cost allowances, that the costs of all items that can be classified as repairs are ipso facto revenue items. ${ }^{19}$

No authority is given for this statement and it is suggested that in Canada, the use of the word "repairs" connotes a currently deductible item. If an item is classified as a capital item, Canadian jurisprudence indicates that it should not be designated as a "repair".

Second is the issue of capital cost allowance. The learned Justice seems to indicate that repair items should be limited as revenue expenditures because we have a capital cost allowance system in Canada. At p. 187 the Exchequer Court observed that in Rhodesia Railways there was no allowance for depreciation on their rails and sleepers "that what the Appellants could not get by way of depreciation, they cannot have been intended to get by way of repairs." ${ }^{20}$ The House of Lords rejected this argument and indeed suggested it should be the opposite. At p. 187 the court in Vancouver Tugboat Company interprets the House of Lords decision in this manner:

One might usefully paraphrase the last clause of the passage above quoted to apply it to this case as follows: ". . . that having been allowed a deduction for wear and tear in the name of capital cost allowance, the Respondent is not entitled to a deduction in the name of repairs to restore the same property to its original condition.

The fundamental problem with this reasoning is that in order to claim capital cost allowance, one must have a capital expenditure. If one has a capital expenditure, this type of expenditure is normally, in Canada, not classified as a repair. In addition, one may take issue with the idea that expenditures made as a result of wear and tear are not properly classified as repairs, and hence, a revenue deduction. ${ }^{21}$

17. Supra n.13, at 257; Also Haddon Hall Realty [1961] C.T.C. 509

18. Supra $\mathrm{n} .3$, at 183.

19. Id., at 187.

20. Supra n.11, at 375.

21. E.G. Lurcott v. Walcely \& Wheeler [1911] 1 K.B. 905 at 923-4; Also, supra n.13, at 257. 
It can be argued that if wear and tear has rendered the asset obsolete, then such a replacement is capital. Support for this argument can be found in the Supreme Court decision of M.N.R. v. Haddon Hall Realty Inc. ${ }^{22}$ However, even this obsolescence concept is tempered by the decision in Canada Steamship Lines Ltd.

With great respect it would have been more useful for the Supreme Court of Canada in M.N.R. v. Haddon Hall Realty Inc..$^{23}$ to have analyzed the concepts to be used in differentiating between repairs and replacements and to attempt to rationalize the jurisprudence in this area. Instead, in a rather short judgment, more questions were raised than answered. This case concerned the taxpayer who owned and operated a large apartment building, and each year from 1950 to 1955 incurred expenses for the replacement of stoves, refrigerators and window blinds which had become womout, obsolete or unsatisfactory. In 1955, this deduction was disallowed by the Minister. The sole question was whether or not such amounts expended in 1955 were allowable as a deduction or were a capital outlay. The rationale of the judgment is found on p. 511 where Mr. Justice Abbott states: ${ }^{24}$

The expenditures to replace capital assets which have become wom out or obsolete are something quite different from those ordinary annual expenditures for repairs which fall naturally into the category of income disbursements.

Does this mean that in order for something to be a repair, it must occur annually? It is suggested that this idea is not supported by the jurisprudence and in fact most of the cases do not involve annual expenditures. The writer is at a loss to explain what repairs "fall naturally" into the category of income disbursements.

In another case, Jackett P., who it is suggested has been one of the most knowledgeable Exchequer Court/Federal Court justices in taxation matters, provides a detailed and thoughtful analysis of the problems facing Canadian courts and tax advisers in the area of repairs and replacements. Canada Steamship Lines Limited v. M.N.R. ${ }^{25}$ involved expenditures incurred in replacing worn or damaged floors, decks and walls in several cargo holds, as well as the cost of replacing the boilers in one ship. The Minister of National Revenue was of the view that such expenditures were capital outlays due to their substantial nature. Justice Jackett had no trouble in finding that the replacement of the floors and walls were repairs and were allowable deductions. With respect to the boilers, Justice Jackett followed Thompson Construction and Vancouver Tugboat. ${ }^{26}$

In analyzing the approach to be taken, Jackett $P$. emphasized that the problem should be viewed from a businessman's point of view. ${ }^{27}$ One must first ascertain the nature of the business asset. In this case, it was the fleet of ships. If the expenditure does not result in a change in that capital asset, the expenditure is a repair. He outlines the arguments at p. 257:

The Minister's argument against the conclusion that I have just expressed may, as I understand it, be summarized as follows:

"The expenditures are in respect of the replacement of a substantial part of the ship's hold which are of 'signal' importance in the operation of a cargo-carrying ship, and the cost of the replacement is substantial when compared with the

22. [1961] C.T.C. 509.

23. Id.

24. Id.

25. [1966] C.T.C. 255.

26. Supra n.13, at 259.

27. Id., at 256-8. 
value of the ship and the cost of repairs done to the ships in other years; such expenditures would therefore be regarded as being for capital repairs or renewals and not for being for current repairs."

I have tried unsuccessfully to appreciate the full significance of the Minister's submission; I have not, however, been able to escape the conclusion that a replacement of a worn or damaged board or plate that is an integral part of an asset used in a business is a repair and that the costs of repairs are current expenses and not outlays of capital. I cannot accept the view that the cost of repairs ceases to be current expenses and becomes outlays of capital merely because the repairs required are very extensive or because the cost is substantial.

Having disposed of the first class of expenditures (i.e. replacing the floors and walls), he turns to the replacement of the boilers, with which he has more difficulty. Mr. Justice Jackett stated at p. 258:

Things used in a business to eam income - land, buildings, plant, machinery, motor vehicles, ships - are capital assets. Money laid out to acquire such assets constitutes an outlay of capital. By the same token, money laid out to upgrade such an asset - to make it something different in kind from what it was - is an outlay of capital. On the other hand, an expenditure for the purpose of repairing the physical effects of use of such an asset in the business - whether resulting from wear and tear or accident - is not an outlay of capital. It is current expense . . . .

In the case of ordinary plant or machinery in a building shop, I should have thought that there is no doubt that each engine and each machine is a capital asset quite separate and distinct from the building in which it is installed and in which it is used. The cost of acquisition of such an asset is, I should have thought, an outlay of capital. On the other hand, in the case of a ship, the function of which involves movement, I should have thought that it was a tenable and arguable view that the equipment or machinery required to affect such movement is, from a businessman's point of view, an integral part of the ship as a capital asset. If this were the right view, I should have thought that the cost of the replacement of the whole of the compulsory machinery or of some unit thereof would be a current expense even though the thing replaced were an asset that, by itself, was an engine or machine that could be installed in a factory as a distinct capital asset.

It is suggested, the learned Justice felt constrained by previous decisions and held that the replacement of the boiler was a capital cost.

Therefore, in Justice Jackett's view, one must take a businessman's approach to this problem. One must isolate what the business capital asset is and assume a functional approach. If the expenditure results in no change in the function of that asset, or is not so extensive as to change the nature of the asset, then it is a current expenditure. One can, therefore, take a less restrictive approach to that which was outlined in Vancouver Tugboat or in Haddon Hall.

The old adage that difficult cases make bad law is well illustrated in Shabro Investments Limited $\mathrm{v}$. The Queen. ${ }^{28}$ Jackett C.J., as a member of the Federal Court of Appeal, was again faced with the same question as to whether or not an expense is a repair or a replacement. In this case, a building was constructed on a landfill site. The peripheral walls were supported by piles which were driven through garbage fill in order to reach solid earth. The flooring was a concrete slab reinforced by wire mesh. It was placed on the fill and dependent on the fill for support. Eventually, the fill compacted causing the floor to subside and break which resulted in a loss of rental space. Water lines, storm drains, plumbing, weeping tiles and electric wiring settled and gave way under the weight of the floor. The damaged floor was replaced by a concrete floor and new steel piles were driven for support.

The Learned Chief Justice had no problem in ascertaining that the cost of the piles was a capital expense. At p. 129, he states:

In my view, installation of the piles was a permanent addition to the structure of the building of a foundation that has not previously existed and was not a repair to the building as it had existed 
prior to the installation. In addition to the essential structure of a building for the period life contemplated for, it does not in my view become a "repair" merely because the necessity for it was overlooked when the building was built and it is added when the lack of it becomes apparent.

Insofar as the outlay was attributable to the removal of the damaged floor, the Learned Chief Justice had more difficulty. He disagreed with the trial judge who found that the work was a capital outlay because the facility lacked the necessary aging and wear. Justice Jackett states, at page 129:

In my view, these are not reasons that necessarily disqualify money spent in remedying damage to the structure of a building from being treated as current expense on repairs. Damage caused by accident or vandalism, just as much as that caused by deterioration from wear or tear or aging, can call for 'repairs' in the profit-loss sense; and similarly, 'repairs' do not become disqualified as 'repairs' in that sense merely because they are carried out in the light of technology unknown when the original structure was built or because they take into account conditions (such as dampness) not taken into account when the original structure was built.

In a footnote to the above quotation, the learned Chief Justice states:

In a limited sense, such repairs may be improvements; but, from a businessman's point of view (which is what is being applied here), within reasonable limits, that is disregarded.

The Chief Justice then indicates that if the floor is to be regarded as a means of remedying the damage to the fabric of the building, it is a repair and deductible as a current expense. However, he concludes that the floor "was an integral component of a work designed to improve the building by replacing its substantial part thereof by something essentially different in kind". He holds that the expenditure was capital. In discussing the functional aspect which he raised in the Canadian Steamship Lines case, the Chief Justice states:

There is no doubt, in this case, from the point of view of the persons making physical use of the building, once the floor was replaced, it was essentially the same as the old floor as it was before it subsided. So regarded, the replacement of the floor could be reganded as a repair of damage to the building. However, from the point of view of the owner or the tenant of the building as such, a building which was 'floating' on garbage fill has been changed into a substantially improved building, namely a building the floor of which is supported by steel piles. Moreover, the removal of the old floor and construction of a floor consisting of a single concrete slab reinforced by steel so as to be suitable for being supported by piles was an essential part of that change. As already indicated with some hesitation, I have come to the conclusion that the problem must be so regarded and that the removal of the old floor, the sinking of the piles and the replacing thereon of a concrete slab reinforced by steel was a single operation whereby an improvement was made to the building that was essentially different in kind from a repair to the building as it originally was.

It is suggested that, by assuming the businessman's point of view, a functionally different building was created when new piles were driven into the ground and a steel-reinforced concrete floor was constructed. On the facts of this case, although one may disagree with the conclusion (and indeed the Chief Justice appears to hesitate in arriving at this conclusion), the tax principle which is applied results in a sound tax consequence.

A concurring judgement was given by Mr. Justice Urie. Two comments are in order. At p. 132, Justice Urie states:

The fact that the floor was only a single component of the lower level of one section of the entire building and in terms of function, it was not superior after the reconstruction to what it was prior thereto does not affect this result. The fact is that, while the function vis-a-vis the building as a whole has not changed, the asset itself has remarkably changed.

It appears the learned Justice is stating that he views the floor itself as a distinct and separate asset. It is respectfully suggested that this view is contrary to the Chief Justice's analysis which clearly indicates that the floor should be viewed in the context of whether or not its replacement resulted in a change to the "fabric of the building". 
Second, Justice Urie states at p. 132:

Thus, while undoubtedly the function to be performed by the subject matter of a renewal, repair or replacement is an element to be considered in characterizing the nature of the work, it is only one element and must be examined, as I see it, against the whole background of the work. Not the least important in this background is the determination of whether or not a simple replacement of the old subject matter would permit the function to be performed satisfactorily. Obviously in this case, it would not.

The inference to be drawn from the above quote is that the steel-reinforced floor must be functionally different because one could not simply lay a new floor in the same manner as was done with the original floor. This can also be expressed in the words used by the court in the Rhodesia Railways case: there was an increase in the functional networth of the building insofar as the owner is concerned. This view is in marked contrast to the Vancouver Tugboat case where the owner businessman could have repaired the Vicker's engine; this replacement was, therefore, a capital expense. In the Shabro case, Mr. Justice Urie seems to say that because the old floor could not be functionally replaced, what was done was something new and hence a capital expenditure.

Thus Shabro Investments Limited is a reaffirmation of the idea that one should approach a repair/replacement problem by attempting to define the asset and then examining the expenditures to see if an innately different asset emerges.

An additional variable is introduced by the court at $p .129,{ }^{29}$ although no detailed analysis is given. This variable is termed new technology. The question arises: does new technology change the "asset" and result in a capital expenditure? Justice Jackett does indicate that simply because a "repair" is undertaken using new technology, the expenditure should not be disqualified as being classified as a "repair".

The problem with this short statement is there is an assumption that a "repair" exists and that, of course, is the issue to be decided. The net result, however, in the Shabro case was that due to new technology, the floor was something so fundamentally different as to change the character of the asset. The tax result, therefore, turns on extremely fine distinctions and degrees of improvement. The technology issue, and its effect in this area of tax, is an important one which adds a further complication.

It is respectfully submitted that the cases of Coleman v. M.N.R. ${ }^{30}$ and Wagner v. M.N.R. ${ }^{31}$ are examples of courts not wishing to allow a revenue deduction, by using a rationale that has been specifically negated by the Federal Court of Appeal. Both of these cases concerned rental properties purchased in poor condition (and presumably for a bargain price). Extensive renovations were completed and as a result higher rents were charged. The court in Coleman states:

It is for reasons that the Minister's assessment must be upheld - the nature of the expenditure

is not that of nommal wear and tear on a building as a result of tenant occupancy in any one year. ${ }^{32}$

This reasoning was specifically rejected in the Wagner case. ${ }^{33}$ Jackett C.J. referred to this principle in the Shabro case twice, and stated that it was inappropriate. The Chief Justice states:

29. Id. at 129.

30. Coleman, supra n.9.

31. Wager, supra n.9, at 2209.

32. S. Coleman v. M.N.R. supra n.9, at 2727.

33. Wager, supra n.9, at 2209. 
As indicated by the reasons quoted, the leamed Trial Judge seems to have taken the view that such expenditures cannot be regarded as a "repair" expenditure because:

(a) The work was not done because of "any wear of the facilities" or "any aging of the materials previously in place" . . .

In my view, these are not reasons which necessarily disqualify expenditures for remedying structural damage from being treated as current expenses on repairs. ${ }^{34}$

Further on, he states:

Insofar as the balance of the amount in question is concerned (viz, that part of the $\$ 95,198.10$ that can reasonably be regarded as cost of replacement or repairing of the water lines, etc.) the learned Trial Judge was of the view that the cost attributable to them must be disallowed because what was done was not due to wear, aging, or deterioration resulting from use or passage of time. 1 am of the view that that is not a reason for disallowing them. ${ }^{35}$

It is respectfully suggested that the same results could have been arrived at in the Coleman and Wagner cases if the Court had decided the asset was so fundamentally altered as to have affected the "fabric of the building." 36 This view would have been consistent with the reasoning in the Shabro case. Alternatively, the Court could have adopted the line of cases which involved the purchase and subsequent renovation of dilapidated buildings. The costs incurred were held to be capital, on the basis that they were really part of the purchase price of the building.

In Healey v. M.N.R. ${ }^{37}$ Christie C.T.J.C. (as he then was) reviewed many of the English and Canadian cases in this area. An automobile agency owned a vacant building which was originally used for the purpose of an automobile dealership. After some unhappy rental experiences, the building was abandoned and became derelict. After approximately three or four years, substantial sums were expended to bring the building back to a rental condition. Judge Christie concluded that the work was of such significance that there was a fundamental change in the character of the building and, therefore, the expenditures were of a capital nature. At p. 2014 Judge Christie states:

The differences are of such magnitude that I should be very surprised that if anyone examined Exhibit A-2(7) and A-5 without knowledge of the history of the property, he or she would conclude that they are [not] photographs of the same premises. In my opinion, what was done was to effect changes so fundamental in the character that they cannot possibly be regarded as "repairs", the cost of which was an expenditure on account of revenue.

Yet another variable was introduced in this case. This variable has to do with whether the character of the expenditure would change if it were made under compulsion of some legal requirement, such as a safety or sanitary code. Judge Christie concluded that this would make no difference.$^{38}$ This issue arises as well in the recent case of Danon Developments Limited ${ }^{39}$ to be discussed below.

The difficulties inherent in attempting to define the "asset" in a particular case are vividly illustrated in Inskip v. M.N.R..$^{40}$ The facts in this case, as set out in the Notice of Appeal, are as follows. The Inskips own 10,006 acres of land which they operate and report as a cattle ranch and their only source of income. In addition,

\author{
34. Supra n.28, at 129. \\ 35. Id., at 131 . \\ 36. Supra n.28. \\ 37. Healey v. M.N.R. [1984] C.T.C. 2004. \\ 38. Page 2015. \\ 39. Danon Developments Ld. v. M.N.R. [1988] I C.T.C. 2266. \\ 40. [1987] 1 C.T.C. 2009.
}


they hold a grazing-only lease on 4,828 acres of adjoining Crown land. The lease was entered into on October 24, 1971 and is to run for 20 years, ending in October 1992. The Crown land incorporated O'Connor Lake and Noble Creek, and Mr. Inskip must periodically obtain a water license to use water from these bodies for irrigation purposes. The dam in question is situated on these waters and on the adjoining Crown land. In October 1978, the Department of Environment inspected the dam, and judged it to be an imminent danger to life and property for both the immediate area, and the North Thompson residential area further down the river. The Inskips and Hayward Holdings, the holders of the immediate water licenses, were ordered to contribute to the repair of the dam and to adhere to government specifications or destroy it. The benefit of this dam extends far past the Inskip holdings to numerous other peoples who were not forced to contribute to its repairs. The government agency, A.R.D.S.A., agreed to pay the largest portion of the cost if the Inskips and Hayward Holdings would divide the balance.

The surveyors, engineers and construction companies were all contracted for, and supervised by, government agencies. The Inskips had no control over, nor were they included in, any of the operations or decisions.

In order to afford this project, the Inskips had to sell an unusually large number of immature cattle, and at a much lower price. The income from this forced sale of the cattle was a direct result of the mandatory repairs to the dam.

Judge Kempo took the view that the asset to be considered was the farming operation and the expenditures did not enhance this business and were therefore deductible repairs. At p. 2015 he states:

\begin{abstract}
I consider that the evidence in its entirety bring to it a common sense appreciation of all the guiding features, weighs in favour of a bona fide expenditure having been made by the Appellant in the course and for the purpose of his regular day to day business operations, it was not, to use the words of Pratte, J. in Glassine, supra, at p. 6083, 'an expenditure incurred for the establishment of the profit-making structure of the Respondent's trade'. It was, in my view, incurred in the operation of that structure. The advantage being sought, in the circumstances of this case, was in respect of the current operations of the Appellant. The expenditure in question prevented that operation from being severely crippled. There is no evidence that the value of the farming operation was any different from its value before the dam reconstruction. Rather than enhancing the business, and thus acquiring an advantage of enduring nature, it likened to an assembly of assets in the capital structure of the business, the expenditures were shown to have merely maintained what had been before.
\end{abstract}

Méthé v. M.N.R. ${ }^{41}$ also illustrates the uncertainty in this area of the law. A rental building was acquired for a relatively modest sum $(\$ 38,000)$ and during the next two years completely renovated at a cost of nearly $\$ 145,000$. The taxpayerdeducted about $\$ 65,000$ as repairs. It was stressed by counsel for the Appellant that the reason the repairs were so extensive was that they had been delayed too long. It was argued that the jurisprudence in this area indicates that the nature and not the costs of the expense was the important factor. This, of course, is precisely what Mr. Justice Jackett stated in Canada Steamship Lines ${ }^{42}$ at p. 257 and indeed in his footnote at the bottom of that page wherein he stated:

Even if repairs are neglected so long as they temporarily prevent the continuance of the business, they are deductible 'when the expenditures are made' and not 'when in the prudent carrying on of the business it ought to have been made.'

41. Methé v. M.N.R. [1986] 1 C.T.C. 2493.

42. Supra n.13. 
The idea that the cost of repairs should not be an influencing factor again was emphasized in the result by the Supreme Court of Canada in Haddon Hall. ${ }^{43}$ The problem, of course, is that where you have a large amount expended, the court may say that such extensive expenditures result in a change in the character of the asset. This is precisely what happened in the Méthé case. At p. 2496, Taylor T.C.J. states:

But in my view, when Mr. Méthé finally finished his work by the year 1982, he did not have the same old building at all that he started with. He had virtually a new building at least certainly a quite different building.

If in order to have a deductible expenditure you must end up with the same old building, one wonders when repairs would ever be deductible?

Again, at p. 2496 the court states:

In the instant appeal, Mr. Méthé at least in part may have brought the building up to modem standards to current residential requirements and demanded, from the view point of appearance, utility and safety. That is not simply doing ordinary repairs and maintenance resulting from day-to-day usage, no matter for how long repairs had been delayed. Perhaps he could not (under today's circumstances) replace 'piece for piece' the building, and even if he could have done so, it would have been a completely uneconomical thing to do, resulting in little or no hope of adequately increasing rental revenue. Clearly, for some of the expenditure, Mr. Méthé was governed by zoning building and construction requirements, which he was required to meet. In effect, once having taken on the task, a major part of its progress was out of his hand. Certainly his intention, an allowable one, at that - whether voluntarily or under some duress, was to transfer the building from a poor investment property into a good one. And that he did. But in the course of so doing, he did much more than mere repairs and maintenance.

Could it be said that the judge was equating the word "maintenance" with the word "repair"? Of course, they are not the same thing.

One of the other variables mentioned previously is again used to classify the expenditure as capital.

There is a second aspect to this situation which deserves comment. Whether during its history before 1980, this building had been 'depreciated' for income tax purposes, was not discussed at the hearing. As a rental property, it was eligible for such treatment. The 'capital cost allowance' charge permitted for income tax purposes, is not merely some intangible accounting concept designed for the reduction of income tax. It does have a relationship to obsolescence and deterioration.

The practical problem is which one of the so-called "tests" should be used in a particular situation. One has no idea when a court will apply one or more of the following: (1) the size of repairs, (2) the fact that in Canada we have a capital cost allowance system, (3) the character of the "asset" in a particular instance, (4) legal obligations imposed on the taxpayer, (5) the use of new technology, or (6) the recurring expense test. The problem is, of course, with so many potential "principles" that could be applied, one never knows in a given instance which one will be applied. Thus, great uncertainty currently exists in Canadian tax law.

Two recent cases illustrate an attempt by latter day courts to liberalize the deductibility of repair expenditures. Goldbar Development Ltd. v. The Queen ${ }^{44}$ re-introduces the concept of a function test though it is certainly not in its purest form. The taxpayer owned an apartment building worth approximately $\$ 8$ million. The exterior bricks of the building were falling off and it was determined that the entire brick facing was unsound. Necessary repairs were carried out which incorporated new building techniques and used metal cladding instead of brick veneer.

43. Supra n.23.

44. Goldbar Development Ldd. v. M.N.R. [1987] 1 C.T.C. 262. 
The cost of these repairs was approximately $\$ 250,000$. The taxpayer attempted to write these expenses off as a current repair and the Minister classified them as capital. Mr. Justice Jerome reviewed several of the Canadian cases in this area and at p. 264 states:

I think it more helpful to emphasize the purpose of the outlay by the taxpayer. What was in the mind of the taxpayer in formulating the decision to spend this money at this time? Was it to improve the capital asset; to make it different; to make it better? That kind of decision involves a very important elective component - a choice or option which is not present in the genuine repair crisis.

Therefore, yet another variable is introduced - the elective nature or the nonelective nature of a particular expenditure. It had been previously suggested that where legal obligations are imposed on a taxpayer, this should make no difference in characterizing the expenditure as either capital or repair. ${ }^{45}$ Is there a difference when a "genuine repair crisis" takes away the voluntariness of the decision?

In deciding the expenditure was a repair expenditure, the Court concluded that, " . . . the plaintiff has this decision forced upon him and did not initiate it." 46 Furthermore, with respect to the technology question, the Court adds at p. 265:

I cannot accept the suggestion, however, that once the decision to repair is forced upon the taxpayer, he must ignore advancement in building techniques and technology in carrying out the work. In remedying the situation, the plaintiff was given two or three options, including the replacement of the original brick. In pursuing the option of curtain-wall cladding, the plaintiff adopted an extremely popular modem construction technique.

One wonders, therefore, whether one can use modern technology only in cases where the repair is forced on the taxpayer?

Curiously, Mr. Justice Jerome did not elect to base any of his decision upon the characterization of the asset and whether or not there had been a fundamental change or upgrading. At one point he states, "I am not satisfied that the appearance of the building was any better than it would have been had the original brick been replaced." 47 This may indicate that in his mind there was no enhancement or improvement or change to the "fabric of the building". ${ }^{48}$ Unfortunately he offers no discussion in relation to this criteria. It is suggested that a conclusion was easily reached in this particular instance, because there was no change to the fabric of the building. However, instead of clarifying the law in this area, the Goldbar case adds yet another ingredient namely, "genuine repair crisis", to the witch's brew.

Another case which indicates an attempt by modern courts to expand the deductibility of certain expenditures is Damon Developments Ltd. v. M.N.R. ${ }^{49}$ The taxpayer corporation operated a hotel business. It attempted to deduct certain expenditures such as the replacement of old drapes, washers and dryers as well as alterations made to its beverage room. Insofar as the replacement of venetian blinds, drapes, dishwashers, etc. was concerned, the Tax Court in this case was faced with an earlier decision of the Supreme Court of Canada in Haddon Hall ${ }^{50}$ in which very similar articles were classified as capital. Thus the Tax Court was forced to distinguish Damon from Haddon Hall on the basis that an apartment building and a hotel are very different businesses. At p. 2269, the court states:

45. Supra n.38, at 2015, supra $\mathrm{n} .41$ at 2496.

46. Supra n.44, at 264.

47. Id., at 265.

48. Supra n.28.

49. Supra n.39.

50. Supra n.23. 
In the present case, the equipment was purchased to replace similar items used in the operation of a hotel business. Because of the nature of the business, the case before us must be distinguished from that of M.N.R. v. Haddon Hall Realty (supra). The replacement of such items as drapes must, because of the type of business, occur at a different rate than that of similar items in an apartment rental business. The appliances have shorter useful lives when used in the operation of the hotel business than when used by tenants in an apartment building.

This introduces yet another variable to what is a virtual dog's breakfast of variables. Is a hotel business different from a motel business which is in turn different from an apartment rental business? At p. 2270, the learned Judge examines the Canada Steamship Lines case and states:

I come to the conclusion that many of the items which were replaced such as drapes, washers and dryers, televisions and mirrors were not distinct capital assets but were part of larger assets used to produce income from the operation of the hotel business.

Would this not have been sufficient grounds to allow the appeal without the introduction of the "different business" concept?

With regard to the beverage room renovations, the conclusion was:

The evidence indicates the changes made were so extensive as to in fact bring into existence a new capital asset. In his testimony, Mr. Graham, purchaser of the hotel, describes the beverage room before the renovation as out of style and in need of repair. He testified the renovation was so extensive that one could see at a glance that very little remained of the old beverage room. Items such as panelling, banquettes and light fixtures were replaced, the design of the room changed. According to Mr. Graham the clientele changed as a result of the renovations.

\section{CONCLUSION}

In Canada today, it is virtually impossible to predict which criteria may be used by a court to determine whether an expenditure is a repair or replacement. It is also impossible to know whether or not a particular expenditure should be capitalized or deducted as a current expense. Is the cost going to be determinative? Are the items replaced to be considered assets in themselves or merely subsidiary to a larger asset? How does capital cost allowance affect the result? What is the nature of the business? Is there a continuing benefit or is something different created by the expenditure? Has the use of technology so altered the character of the asset that it becomes a capital expenditure? Is the expenditure voluntary or imposed by some third party? Should this matter? It has been emphasized in many cases ${ }^{51}$ that no matter what, the criterion is the key to solving the problem. In Canada, however, we have introduced so many vague criteria that almost any factual situation could be decided in any way. One of the fundamental principles of tax law is certainty. It is suggested that in this area of taxation, the law is so uncertain as to render any advice impotent. This situation is anything but satisfactory and is a disservice to the taxpayers of this country.

The following is offered for consideration as a possible solution to the dilemma in which we find ourselves. It might be called "a modified functional approach" or "a functional/networth approach". That is, if after the expenditure, the asset performed the same function, it should be classified as a repair and therefore deductible. It has been suggested that this approach would result in much too wide an area of deductibility. For example, an extreme case might be if one replaced an apartment block with a new apartment block, the second apartment block served the same 
function and hence the cost should be deductible. This clearly would be unacceptable. However, the function approach does have the practical attraction of relative certainty and ease of evidence. It is submitted these traits are admirable and an attempt to preserve them should be made, if possible.

How could this be accomplished without the inherent negative effects of a "pure" functional approach? It is suggested that many of the current problems stem from the fact that courts have traditionally looked at the physical asset rather than its place in the business stream. It is proposed therefore that the modification to the "pure" functional approach would be to approach the problem from an operational point of view. If the expenditure resulted in a "networth" increase in the business operation, then the expenditure should be classified as capital. It was this taxpayer's approach that was emphasized by Mr. Justice Jackett in Canada Steamship Lines. Therefore, taken from a taxpayer's operational business point of view (as distinct from an individual asset point of view) did the expenditure increase the networth of the business operation? Reception of this idea is found in cases like Rhodesia Railways Limited and Inskip ${ }^{52}$.

If such an approach had been taken earlier, what effect would it have had on Canadian jurisprudence? In the Vancouver Tugboat Company case, because the new engine did not produce any more power, and did not allow the tug to go any faster than before, it is suggested that if the modified functional approach had been taken, the deduction for the new engine would have been allowed. It is also suggested that this would not have been a bad change.

As far as Haddon Hall Realty is concerned, if the facts had shown there was no increase in rent or innate upgrading of clientele, the expense would have been deducted. It is suggested this would have been a fair result.

In Canada Steamship Lines, if this proposed test had been applied, the result would have been the same with regard to the floors and the walls, assuming no more cargo was carried as a result of the repairs. Furthermore, the test would have allowed the expense of the boilers, as long as the boilers performed the same function and provided the ship with the same power. The test probably would have allowed the deduction Justice Jackett appeared to prefer.

In the Shabro case, if the new floor did not result in any increased rent or change in type of tenant, the expense would have been allowed. If, however, as a result of the new floor, greater rents could be charged, the expense would have been capitalized.

In the cases of Stephen Coleman and Audrey Wager, the renovations clearly resulted in a change in the operation of the business by permitting higher rents. Thus, the tax result would have been the same - capitalization of the expenditures. The same would have applied in the Healey case.

It is suggested the same result would have occurred in the Inskip case if the new test was applied. In that case there was no increase operationally in the networth of the cattle ranch operation. In the Méthé case, it is suggested, the results under the proposed new test and those applied in the case would have been the same because it was stated in the case that the new effect of the expenditure was "to transform the building from a poor investment property into a good one". Therefore, 
the costs would be capitalized. With respect to Goldbar Developments Ltd. , again the results would be the same in that there was no evidence the new metal-cladding wall increased the functional networth of the building.

Finally, with respect to Danon Developments, if the proposed new test had been applied, the results again would have been the same. The evidence seemed to indicate that the replacement of the drapes, washers and dryers did not result in any operational benefit for the hotel business. However, the renovations to the beverage room did result in a change of clientele. ${ }^{53}$ Assuming this change was a positive one in the operation of the beverage room, the expenditure would, under the proposed test, be capitalized.

Overall, if the test proposed were applied to the above factual situations, the result would be a slight broadening of what would be allowable as a repair deduction. The result would not be too radical and, it is suggested, would be well within the limits of a wider trend towards broadening allowable business deductions. ${ }^{54}$ In any event, it is hoped these suggestions are food for thought.

53. Danon Developments Ld., supra n.39, at 2271.

54. M.N.R. v. Dominion Natural Gas [1940-41] C.T.C. 155; British Columbia Electric Railway v. M.N.R. [1958] C.T.C. 21; The Queen v. Farquhar Bethune Insurance Led. [1982] C.T.C. 282; The Queen v. Stirling [1985] 1 C.T.C. 275; John-Manville Canada Inc. v. The Queen [1985] 2 C.T.C. 111. 